\title{
Trypanocidal, trichomonacidal and cytotoxic components of cultivated Artemisia absinthium Linnaeus (Asteraceae) essential oil
}

\author{
Rafael Alberto Martínez-Díaz ${ }^{1 /}$, Alexandra Ibáñez-Escribano² ${ }^{2}$ Jesús Burillo ${ }^{3}$, Lorena de las Heras ${ }^{1}$, \\ Gema del Prado', M Teresa Agulló-Ortuño ${ }^{4}$, Luis F Julio ${ }^{5}$, Azucena González-Coloma ${ }^{5}$ \\ `Universidad Autónoma de Madrid, Facultad de Medicina, Departamento de Medicina Preventiva, Salud Pública y Microbiología, \\ Madrid, Spain ${ }^{2}$ Universidad Complutense de Madrid, Campus de Excelencia Internacional Moncloa, Facultad de Farmacia, \\ Departamento de Parasitología, Madrid, Spain ${ }^{3}$ Gobierno de Aragón, Centro de Investigación y Tecnología Agroalimentaria, \\ Madrid, Spain ${ }^{4}$ Instituto de Investigación Hospital 12 de Octubre, Translational Oncology, Madrid, Spain \\ ${ }^{5}$ Consejo Superior de Investigaciones Científicas, Instituto de Ciencias Agrarias, Madrid, Spain
}

Artemisia absinthium is an aromatic and medicinal plant of ethnopharmacological interest and it has been widely studied. The use of $\mathrm{A}$. absinthium based on the collection of wild populations can result in variable compositions of the extracts and essential oils (EOS). The aim of this paper is the identification of the active components of the vapour pressure (VP) EO from a selected and cultivated A. absinthium Spanish population (T2-11) against two parasitic protozoa with different metabolic pathways: Trypanosoma cruzi and Trichomonas vaginalis. VP showed activity on both parasites at the highest concentrations. The chromatographic fractionation of the VP T2-11 resulted in nine fractions (VLC1-9). The chemical composition of the fractions and the antiparasitic effects of fractions and their main compounds suggest that the activity of the VP is related with the presence of trans-caryophyllene and dihydrochamazulene (main components of fractions VLC1 and VLC2 respectively). Additionally, the cytotoxicity of VP and fractions has been tested on several tumour and no tumour human cell lines. Fractions VLC1 and VLC2 were not cytotoxic against the nontumoural cell line HS5, suggesting selective antiparasitic activity for these two fractions. The VP and fractions inhibited the growth of human tumour cell lines in a dose-dependent manner.

Key words: Artemisia absinthium - essential oil - activity - Trypanosoma cruzi - Trichomonas vaginalis - cytotoxicity

The Artemisia genus belongs to the family Compositae (Asteraceae) and consists of about 500 species distributed through the world. Artemisia absinthium L. is an aromatic and medicinal plant of ethnopharmacological interest (Bora \& Sharma 2010, Lachenmeier 2010).The composition and biological effects of the essential oil (EO) and the extracts of $A$. absinthium have been widely studied. Different researches have demonstrated its antimicrobial and antiprotozoal effects against Leishmania aethiopica, Leishmania donovani, Leishmania infantum and Trypanosoma cruzi (Juteau et al. 2003, Tariku et al. 2011, Erel et al. 2012, Nasrabadi et al. 2012, Bailén et al. 2013, Bachrouch et al. 2015).

Among the major A. absinthium EO components reported are $\alpha$ and $\beta$-thujone, myrcene, trans-sabinyl acetate, $\beta$-pinene, 1,8-cineole, camphor, cis-epoxyocimene, chrysanthenyl acetate, sabinene, myrtenol, bornyl acetate, artemisiaketone, linalool, hydrocarbon monoterpenes, sesquiterpene lactones (Pino et al. 1997, Jaenson

doi: 10.1590/0074-02760140129

Financial support: MICINN (CTQ2012-38219-C03-01), JAE-CSIC (predoctoral fellowship to LFJ), CEI Moncloa (PICATA predoctoral fellowship to AI-E)

+Corresponding author: rafael.martinez@uam.es

Received 27 March 2015

Accepted 3 June 2015 et al. 2005, Kordali et al. 2005, Geszprych et al. 2010, Martín et al. 2011, Erel et al. 2012, Judzentiene et al. 2012, Sharopov et al. 2012, Tehrani et al. 2012, Umpiérrez et al. 2012) and mixtures of some of these components, depending on the plant origin (Chialva et al. 1983, Carnat et al. 1992, Geszprych et al. 2010, Bailén et al. 2013). In fact, the use of $A$. absinthium based on the collection of wild populations can result in variable compositions of the extracts and EOs.

A. absinthium is abundant in the mountains of the Iberian Peninsula, where seven chemotypes have been described (Ariño et al. 1999). Two Spanish populations of wormwood have been domesticated for experimental cultivation in the field and under controlled conditions (Burillo 2009, Martín et al. 2011, González-Coloma et al. 2012a). Based on these results, a long-term field cultivation of selected A. absinthium plants has been established for further valorisation of its extracts.

The aim of the present paper is the identification of the active components of the vapour pressure (VP) EO from a selected and cultivated $A$. absinthium Spanish population against two parasitic protozoa with different metabolic pathways, T. cruzi and Trichomonas vaginalis.

T. cruzi is the aetiologic agent of Chagas disease, a frequently fatal illness affecting the heart and gastrointestinal systems. An estimated eight million people in Latin America are infected with this pathogen and it is also spreading to the United States of America, Canada and many parts of Europe and the Western Pacific as a result of migratory flows (Rassi Jr et al. 2010). Only two drugs, nifurtimox (NFX) and benznidazole are in use 
against chronic infections and both have limitations, due to the need of a large number of doses over a long time period, side effects and lack of effectiveness against all stages of the disease and all strains of the parasite. Moreover, their lack of efficiency has involved problems in their production and distribution (González-Coloma et al. 2012b).

T. vaginalis is a parasitic protozoa and a major cause of vaginitis, cervicitis and urethritis in women and may cause nongonococcal urethritis, prostatitis and other genitourinary tract syndromes in men. Trichomoniasis is among the world's most common sexually transmitted diseases with an annual incidence of more than 276 million cases per year (WHO 2012). Its clinical manifestations vary from asymptomatic infection to an acute vaginitis. A single drug, metronidazole, is currently available for treating trichomoniasis. However, metronidazole resistant strains have been found in unsuccessfully treated patients and some adverse effects have been described (Dunne et al. 2003, Cudmore et al. 2004).

Natural products could be a source of new drugs. In this paper the antiparasitic effects of a characterised A. absinthium VP EO against T. cruzi and T. vaginalis will be discussed along with the chemical composition of the active fractions. Additionally, their selective cytotoxicity has been tested on several tumoural (A549, H292, HCT116, MCF7, SK-MEL5) and nontumoural (HS5) human cell lines.

\section{MATERIALS AND METHODS}

Plant material and cultivation - The individuals for field cultivation were obtained from selected seeds $(A$. absinthium var. candial ${ }^{\mathbb{}}$ ) and planted in Ejea de los Caballeros (Zaragoza, Spain) in 2008. A detailed description of the field and the cultivation parameters has been reported (Burillo 2009). Flowering plants were harvested yearly and processed for VP extraction. The material under study is endotoxin free.

EO analysis - Plant material was distilled in an industrial stainless steel VP extraction plant equipped with two $3000 \mathrm{~L}$ vessels (ecoaromuz.com). The VP EO extracted was analysed by gas chromatography mass spectrography (GC-MS) using an Agilent 6890N GC (Agilent Technologies, USA) coupled to an Agilent 5973N mass detector (electron ionisation, $70 \mathrm{eV}$ ) (Agilent Technologies) and equipped with a $25 \mathrm{~m} \times 0.20 \mathrm{~mm}$ i.d. capillary column $(0.2 \mu \mathrm{m}$ film thickness) HP-1 (methyl silicone bonded) (Hewlett-Packard). Working conditions were as follows: split ratio $(20: 1)$, injector temperature $260^{\circ} \mathrm{C}$, temperature of the transfer line connected to the mass spectrometer $280^{\circ} \mathrm{C}$, initial column temperature $70^{\circ} \mathrm{C}$, then heated to $270^{\circ} \mathrm{C}$ at $4^{\circ} \mathrm{C} \mathrm{min}^{-1}$. Electron ionisation mass spectra and retention data were used to assess the identity of compounds by comparing them with those of standards or found in the Wiley Mass Spectral Database (2001). Quantitative data were obtained from the total ion current peak areas without the use of response factors.

Fractionation of the EO - A VP extract of A. absinthium (20 g, T2 population, 2011) was submitted to vacuum liquid chromatography on a Si-gel column $(40-70 \mu \mathrm{m}, 6 \mathrm{~cm}$ diameter, $9 \mathrm{~cm}$ length) eluted with a hexane ( $\mathrm{Hx})$ :dichloromethane (DCM) gradient of increasing polarity $(0.5-100 \% \mathrm{DCM})$.
Nine fractions were obtained and analysed by GC-MS as described. Fraction 8 (690 mg) was further purified by flash chromatography on a $2.5 \mathrm{~cm}$ diameter silica cartridge $(40-70 \mu \mathrm{m})$ eluted with a Hx:DCM (70:30) mixture (isocratic, $18 \mathrm{~mL} / \mathrm{min}$ flow rate) and by Sephadex LH-20 chromatography [DCM: methanol (MeOH), 1:1] to give (-)-cischrysanthenol (4) (33.5 mg; 4.9\%).

All solvents used were of analytical grade. n-Hx, DCM and $\mathrm{MeOH}$ were obtained from Lab-Scan Analytical Sciences (Poland). Silica gel (70-30 mesh) and thin layer chromatography plate (silica gel 60F254) was purchased from Merck Co (Germany). (-)-cis-chrysanthenol was isolated from A. absinthium EO (VP extract) and trans-caryophyllene $80 \%$ was purchased from Sigma-Aldrich (USA).

The VP EO is constituted by apolar substances and the activity assays are performed in aqueous culture media. To the tests, VP, fractions and products are previously dissolved in acetone at an initial concentration of $10 \mathrm{mg} / \mathrm{mL}$. From this initial solution, the different concentrations for assays are prepared using the culture medium of cells and parasites.

Trypanocidal in vitro activity - Trypanocidal activity was assayed on epimastigote forms of $T$. cruzi $\mathrm{Y}$ strain, cultured in liver infusion tryptose medium supplemented with $10 \%$ heat-inactivated foetal calf serum. Parasites in logarithmic growth phase from an initial culture with $2 \times 10^{6}$ epimastigotes $/ \mathrm{mL}$ were distributed in 96-well flat-bottom plates. Each well was filled with $90 \mu \mathrm{L}$ of culture after two days of incubation. VP, factions and compounds were tested at several concentrations (VP at $800,400,200,100,10$ and $1 \mu \mathrm{g} / \mathrm{mL}$; fractions and compounds at 100,10 and $1 \mu \mathrm{g} / \mathrm{mL}$ ) for $72 \mathrm{~h}$. NFX was used as the reference drug and parasite viability was analysed by a modified 3-(4,5-dimethylthiazol-2-yl)-2,5-diphenyltetrazolium bromide (MTT) colorimetric assay method (González-Coloma et al. 2012b). Briefly, after 72 h, $10 \mu \mathrm{L} \mathrm{MTT/phenazine} \mathrm{methosulfate} \mathrm{were} \mathrm{added} \mathrm{to} \mathrm{each}$ well. Incubate $75 \mathrm{~min}$ to occur the reduction of MTT and $100 \mu \mathrm{L}$ sodium dodecyl sulphate were added to dissolve formazan crystals obtained as a result of the reduction of MTT. Once the crystals have dissolved (15-30 min), the plate was read on a spectrophotometer at $570 \mathrm{~nm}$. The activity was calculated as percentage growth inhibition (\%GI) as follows: $\% \mathrm{GI}=100-[(A p-A b) /(A c-$ $A b)]$ x 100 , where $A p$ being the absorbance of problem wells (treated), $A c$ the absorbance of control wells (not treated) and $A b$ the absorbance of blank wells (culture medium and vehicle only). All assays were carried out in triplicate and were repeated at least three times independently to confirm the results. The concentration that inhibits $50 \%$ the growth of the parasites $\left(\mathrm{GI}_{50}\right)$ as well as the $95 \%$ confidence intervals (CIs) were calculated by Probit analysis (SPSS v.20, IBM).

Activity on T. vaginalis - Trichomonacidal assays were carried out against the metronidazole-sensitive T. vaginalis JH31A no. 4 isolate [American Type Culture Collection, (ATCC)]. The flagellates were cultured in trypticase-yeast extract-maltose modified medium supplemented with $10 \%$ heat-inactivated foetal bovine serum (FBS) and antibiotic solutions at $37^{\circ} \mathrm{C}$ and $5 \%$ 


\section{TABLE I}

Gas chromatography mass spectrography analysis of the Artemisia absinthium vapour pressure (VP) essential oil (T2-11) and its fractions

\begin{tabular}{|c|c|c|c|c|c|c|c|c|c|c|}
\hline \multirow[b]{2}{*}{ Compound } & \multirow{2}{*}{$\begin{array}{c}\text { VP } \\
\text { T2-11 }\end{array}$} & \multicolumn{9}{|c|}{ Fraction } \\
\hline & & VLC1 & VLC2 & VLC3 & VLC4 & VLC5 & VLC6 & VLC7 & VLC8 & VLC9 \\
\hline Yield & - & 12.6 & 4 & 0.8 & 7.6 & 5.3 & 13.5 & 4.8 & 7.8 & 1.7 \\
\hline Linalool (1) & 2 & - & - & - & - & - & - & - & 17.3 & - \\
\hline cis-epoxycimene (2) & 39.8 & - & - & - & 13.5 & 63.9 & 86.6 & 5.6 & - & - \\
\hline Camphor (3) & 4.5 & - & - & - & - & 1.4 & 7.2 & 27 & - & - \\
\hline (-)-cis-chrysanthenol (4) & 11.9 & - & - & - & - & - & - & 60.8 & 63 & 0.7 \\
\hline (E)-3-hexenyl butyrate (5) & 1.1 & - & - & - & - & - & - & 1.7 & 12.4 & - \\
\hline Chrysanthenyl acetate (6) & 5.3 & - & - & 1 & 35.7 & 22.1 & 0.9 & - & - & - \\
\hline (-)-(5Z)-2,6-dimethylocta-5,7-diene-2,3-diol (7) & 2 & - & - & - & - & - & - & - & - & 67.8 \\
\hline trans-caryophyllene (8) & 3.8 & 29.5 & - & - & - & - & - & - & - & - \\
\hline Germacrene-D (9) & 2.3 & 15.5 & - & - & - & - & - & - & - & - \\
\hline$\beta$-selinene (10) & 1.1 & 8.8 & - & - & - & - & - & - & - & - \\
\hline 3,6-dihydrochamazulene (11) & 5.8 & 2.5 & 42.5 & 7.9 & - & - & - & - & - & - \\
\hline Chamazulene (12) & 2.6 & 1.1 & 41.4 & 81.7 & - & - & - & - & - & - \\
\hline
\end{tabular}

data are expressed as relative abundance $(\%)$.

$\mathrm{CO}_{2}$. Assays were carried out in glass tubes containing $10^{5}$ trophozoites $/ \mathrm{mL}$. After 5-6 h of seeding, the VP, factions and compounds were added to log-phase growth cultures at several concentrations $(500,250,100,75,37.5$ and $18.75 \mu \mathrm{g} / \mathrm{mL})$. The tubes were incubated for $24 \mathrm{~h}$ at $37^{\circ} \mathrm{C}$ and $5 \% \mathrm{CO}_{2}$. The trichomonacidal activity was obtained by a fluorimetric method using resazurin (SigmaAldrich) as previously described (Escribano et al. 2012). The experiments were performed at least two times in triplicate. $\mathrm{GI}_{50}$ values as well as the $95 \%$ CI were calculated by Probit analysis (SPSS v.20, IBM).

Cytotoxicity assays - The A549, NCI-H292 (adenocarcinoma and squamous non-small cell lung cancer, respectively), HCT116 (colorectal carcinoma), MCF7 (luminal breast adenocarcinoma), SK-MEL-5 (melanoma) and HS5 (bone marrow stromal) human cell lines were employed to determine the toxicity of the VP and fractions. HS5 was used as nontumour control cells. Cell lines were purchased from LGC Promochem, SLU-ATCC (Spain). All cell lines were propagated in RPMI-1640 medium, supplemented with $10 \%$ heat-inactivated FBS, $100 \mathrm{U} / \mathrm{mL}$ penicillin, $100 \mu \mathrm{g} / \mathrm{mL}$ streptomycin and $2 \mathrm{mM}$ glutamine (Lonza Verviers). Cells were grown at $37^{\circ} \mathrm{C}$ in a humidified atmosphere with $5 \% \mathrm{CO}_{2}$ and were in the logarithmic growth phase at the initiation of the experiments. For the determination of the activity, cells diluted in $100 \mu \mathrm{L} /$ well of complete cell culture medium were plated in 96-well flat-bottom plates and allowed to attach for $24 \mathrm{~h}$. Growth medium was removed from the wells and replaced by medium containing the VP or fractions at concentrations of 100 and $250 \mu \mathrm{g} / \mathrm{mL}$ for another $72 \mathrm{~h}$. The anticancer drugs paclitaxel (a cyclic diterpene) and cisplatin (drug based on the platinum) were tested as reference products. All experimental points were set up in four wells and all were confirmed in at least three independent experiments. Viable cells were determined using the WST-1 assay (Roche, Germany) according to the manufacturer's protocol.

\section{RESULTS AND DISCUSSION}

Table I shows the composition of the VP and its fractions. cis-epoxyocimene was the major component (40\%) followed by (-)-cis-chrysanthenol (12\%), dihydrochamazulene $(6 \%)$ and chrysanthenyl acetate (5.3\%). Camphor (4.5\%), trans-caryophyllene (4\%) and chamazulene (3\%) were also present. Linalool, (-)-(5Z)2,6-dimethylocta-5,7-diene-2,3-diol, germacrene-D, $\beta$-selinene, (E)-3-hexenyl butyrate were found in low amounts ranging between $1-2.3 \%$.

Two chemotypes have been described from the Iberian Peninsula (Ariño et al. 1999); cis-epoxyocimene type and a cis-epoxyocimene + chrysanthenyl acetate type. The cultivated Spanish wormwood population VP used in this work showed cis-epoxyocimene + cischrysanthenol chemotype. Similarly, the population that originated this selected germplasm showed a similar VP composition (Bailén et al. 2013).

The antiparasitic effects of the VP and its fractions are shown in Tables II, III. The VP was active on T. cruzi up to a concentration of $200 \mu \mathrm{g} / \mathrm{mL}$, showing GI of $100 \%$ at $800 \mu \mathrm{g} / \mathrm{mL}, 96 \%$ at $400 \mu \mathrm{g} / \mathrm{mL}$ and $83.6 \%$ at $200 \mu \mathrm{g} /$ $\mathrm{mL}\left(\mathrm{GI}_{50} 144.6 \mu \mathrm{g} / \mathrm{mL}\right)$, in agreement with the bioactivity reported for the parent population EO (Bailén et al. 2013). This VP also showed a trichomonacidal effect (Table III) with GI of $99.1 \%$ at $500 \mu \mathrm{g} / \mathrm{mL}, 87.4 \%$ at 250 $\mu \mathrm{g} / \mathrm{mL}$ and $53.7 \%$ at $100 \mu \mathrm{g} / \mathrm{mL}\left(\mathrm{GI}_{50} 87.2 \mu \mathrm{g} / \mathrm{mL}\right)$.

Among the VP fractions, VLC1 and 2 were the most active on T. cruzi (nearly $100 \%$ mortality at $100 \mu \mathrm{g} / \mathrm{mL}$ ) (Table II). Seven of the nine VLC fractions (1, 2, 4-8) 
TABLE II

Trypanocidal activity of Artemisia absinthium vapour pressure (VP) essential oil (T2-11), fractions VLC1-VLC9, trans-caryophyllene and (-)-cis-chrysanthenol

\begin{tabular}{|c|c|c|c|c|c|c|}
\hline \multirow{2}{*}{$\begin{array}{l}\text { VP, } \\
\text { fractions } \\
\text { and compounds }\end{array}$} & \multicolumn{6}{|c|}{$\begin{array}{l}\text { Concentration } \\
\qquad(\mu \mathrm{g} / \mathrm{mL})\end{array}$} \\
\hline & 800 & 400 & 200 & 100 & 10 & 1 \\
\hline VP T2-11 & $100 \pm 1.7$ & $96.0 \pm 11.2$ & $83.6 \pm 18.0$ & $33.0 \pm 7.2$ & $5.8 \pm 5.2$ & $4.7 \pm 4.9$ \\
\hline VLC1 & - & - & - & $97.8 \pm 4.6$ & $0.6 \pm 1.8$ & $0.5 \pm 1.1$ \\
\hline VLC2 & - & - & - & $94.7 \pm 8.4$ & $1.5 \pm 2.3$ & $1.3 \pm 2.2$ \\
\hline VLC3 & - & - & - & $30.0 \pm 5.4$ & $0.9 \pm 1.7$ & $0.0 \pm 0.0$ \\
\hline VLC4 & - & - & - & $46.7 \pm 15.3$ & $2.0 \pm 3.8$ & $4.5 \pm 4.2$ \\
\hline VLC5 & - & - & - & $26.8 \pm 15.9$ & $1.0 \pm 1.3$ & $0.5 \pm 1.8$ \\
\hline VLC6 & - & - & - & $8.4 \pm 6.4$ & $1.6 \pm 2.0$ & $3.3 \pm 4.3$ \\
\hline VLC7 & - & - & - & $10.1 \pm 7.6$ & $0.0 \pm 0.0$ & $4.8 \pm 5.9$ \\
\hline VLC8 & - & - & - & $41.9 \pm 10.1$ & $11.1 \pm 5.6$ & $4.5 \pm 3.7$ \\
\hline VLC9 & - & - & - & $6.5 \pm 8.1$ & $0.8 \pm 1.4$ & $1.4 \pm 2.3$ \\
\hline trans-caryophyllene (8) & - & - & - & $99.4 \pm 1,9$ & $11.6 \pm 14.1$ & $5.4 \pm 5.5$ \\
\hline (-)-cis-chrysanthenol (4) & - & - & - & $3.5 \pm 8.3$ & $0.0 \pm 0.0$ & $0.4 \pm 0.7$ \\
\hline NFX & - & - & - & $99.9 \pm 0.2$ & $100.0 \pm 0.5$ & $20.8 \pm 2.8$ \\
\hline
\end{tabular}

nifurtimox (NFX) is included as drug reference. Data are expressed as percentage of growth inhibition \pm standard deviation.

showed trichomonacidal effect $(>70 \%)$ at $500 \mu \mathrm{g} / \mathrm{mL}$, but only VLC1 maintained significant activity $(81.6 \%)$ at $100 \mu \mathrm{g} / \mathrm{mL}$. VLC4 and VLC8 were also active at 250 $\mu \mathrm{g} / \mathrm{mL}$ (Table III).

Fractions VLC1 and 2 were not cytotoxic against nontumour cell line HS5, suggesting selective antiparasitic activity for these two fractions (Table IV).

Fraction VLC1 is characterised by trans-caryophyllene (29.5\%), germacrene D (15.5\%) and $\beta$-selinene $(8.8 \%)$. Fraction VLC2 contained dihydrochamazulene $(42.5 \%)$ and chamazulene (41.4\%). The main component of VLC8 is (-)-cis-chrysanthenol (63\%) (Figure, Table I).

trans-caryophyllene showed a remarkable activity against T. cruzi (Table II) with GI of $99.4 \%$ at $100 \mu \mathrm{g} / \mathrm{mL}$ $\left(\mathrm{GI}_{50} 39.2 \mu \mathrm{g} / \mathrm{mL}\right)$. This compound also showed significant trichomonacidal effect (Table III) with GI of 100\% at $500 \mu \mathrm{g} / \mathrm{mL}, 99 \%$ at $250 \mu \mathrm{g} / \mathrm{mL}, 80.3 \%$ at $100 \mu \mathrm{g} / \mathrm{mL}$ and $53.7 \%$ at $75 \mu \mathrm{g} / \mathrm{mL}\left(\mathrm{GI}_{50} 68.7 \mu \mathrm{g} / \mathrm{mL}\right)$. The antiparasitic effects of VLC1 against $T$. cruzi and T. vaginalis can be partially attributed to trans-caryophyllene.

The activity of VLC2 on T. cruzi cannot be attributed to chamazulene since fraction VLC3, containing $81.7 \%$ chamazulene, was inactive. Therefore, dihydrochamazulene or the mixture of both compounds could be responsible for this effect. Furthermore, neither VLC2 nor VLC3 showed trichomonacidal activity at $100 \mu \mathrm{g} / \mathrm{mL}$, suggesting a selective activity (alone or in synergy) of dihydrochamazulene on T. cruzi.

(-)-cis-chrysanthenol also showed activity against T. vaginalis with GI of $100 \%$ at $500 \mu \mathrm{g} / \mathrm{mL}, 96.3 \%$ at $250 \mu \mathrm{g} / \mathrm{mL}, 54.5 \%$ at $100 \mu \mathrm{g} / \mathrm{mL}$ and $45.4 \%$ at $75 \mu \mathrm{g} /$ $\mathrm{mL}\left(\mathrm{GI}_{50} 87.2 \mu \mathrm{g} / \mathrm{mL}\right)$ (Table III). The effects of VLC8 against $T$. vaginalis at high concentrations can be attributed to (-)-cis-chrysanthenol.
When tested against tumour cell lines, the VP and fractions inhibited the growth of human tumour cell lines in a dose-dependent manner (Table IV). We carried out parallel experiments with cisplatin and paclitaxel on cells plated at the same time from a single flask to serve as reference cytotoxicity. Doses used for these two compounds are those that lead to a $50 \%$ of GI in most tumour cell lines.

For the fractions tested, the most sensitive cell lines were SK-MEL-5 (melanoma) and HCT116 (colorectal adenocarcinoma). MCF-7 (luminal breast adenocarcinoma) was the less sensitive tumour cell line. VP and VLC-1 were the most active fractions for the majority of cell lines, being also remarkable cytotoxic effects of VLC-5 and VLC-8 fractions. Moreover, VP and VLC-1 also showed activity against A549 and H292 cell lines (adenocarcinoma and squamous nonsmall cell lung cancer). These cytotoxic effects may be due to the presence of trans-caryophyllene and/or germacrene D in the VP and fractions. The cytotoxic activity of trans-caryophyllene on animal and human tumour cells has been previously described by other authors (el Hadri et al. 2010).

It is noteworthy that these fractions had little or no cytotoxic effect against the nontumour cell line, HS5, suggesting selective cytotoxic activity for these fractions. This would be an important biological effect and could provide new rational basis for the design of new antitumour compounds.

EOs rich in chamazulene showed variable growth-inhibitory effects on human cancer cell lines with $\mathrm{GI}_{50}$ values ranging from $14.3 \mu \mathrm{g} / \mathrm{mL}$ on A375 (human malignant melanoma cell line) to $59.8 \mu \mathrm{g} / \mathrm{mL}$ on T98G (human glioblastoma cell line) (Ornano et al. 2013) and strong antifungal properties against dermatophytes and opportunistic saprophytes (Jamalian et al. 2012). Chamazulene has 
TABLE III

Trichomonacidal activity of Artemisia absinthium vapour pressure (VP) essential oil (T2-11), fractions VLC1-VLC9, trans-caryophyllene and (-)-cis-chrysanthenol

VP,

fractions and compounds
Concentration $(\mu \mathrm{g} / \mathrm{mL})$

\begin{tabular}{|c|c|c|c|c|c|c|}
\hline VP T2-11 & $99.1 \pm 0.4$ & $87.4 \pm 1.3$ & $53.7 \pm 0.5$ & $51.7 \pm 3.3$ & $14.5 \pm 2.4$ & $0.8 \pm 1.2$ \\
\hline VLC1 & $99.3 \pm 0.2$ & $98.8 \pm 0.2$ & $81.6 \pm 0.2$ & $47.6 \pm 3.8$ & $10.3 \pm 2.0$ & $0.4 \pm 0.5$ \\
\hline VLC2 & $100 \pm 0.0$ & $44.3 \pm 5.6$ & $11.8 \pm 4.0$ & $2.7 \pm 3.9$ & $1.2 \pm 1.7$ & $0.0 \pm 0.0$ \\
\hline VLC3 & $35.5 \pm 0.1$ & $12.2 \pm 2.9$ & $10.3 \pm 2.0$ & $0.4 \pm 0.5$ & $1.0 \pm 1.4$ & $0.0 \pm 0.0$ \\
\hline VLC4 & $99.5 \pm 0.1$ & $99.4 \pm 0.1$ & $39.1 \pm 0.2$ & $27.0 \pm 3.2$ & $4.0 \pm 0.1$ & $0.0 \pm 0.0$ \\
\hline VLC5 & $99.3 \pm 0.4$ & $43.3 \pm 2.6$ & $2.4 \pm 3.4$ & $3.7 \pm 5.3$ & $0.0 \pm 0.0$ & $0.0 \pm 0.0$ \\
\hline VLC6 & $71.6 \pm 1.3$ & $36.5 \pm 1.8$ & $4.7 \pm 6.6$ & $2.5 \pm 3.6$ & $0.4 \pm 0.6$ & $0.0 \pm 0.0$ \\
\hline VLC7 & $100.0 \pm 0.0$ & $47.9 \pm 4.3$ & $27.0 \pm 6.8$ & $0.0 \pm 0.0$ & $0.0 \pm 0.0$ & $0.0 \pm 0.0$ \\
\hline VLC8 & $99.9 \pm 0.6$ & $92.2 \pm 0.1$ & $0.0 \pm 0.0$ & $0.0 \pm 0.0$ & $0.0 \pm 0.0$ & $0.0 \pm 0.0$ \\
\hline VLC9 & $4.7 \pm 6.7$ & $1.7 \pm 2.5$ & $0.0 \pm 0.0$ & $1.7 \pm 2.4$ & $0.0 \pm 0.0$ & $0.5 \pm 0.7$ \\
\hline trans-caryophyllene (8) & $100.0 \pm 0.0$ & $99.0 \pm 0.2$ & $80.3 \pm 7.3$ & $53.7 \pm 2.2$ & $34.3 \pm 6.0$ & $19.9 \pm 8.5$ \\
\hline (-)-cis-chrysanthenol (4) & $100.0 \pm 0.0$ & $96.3 \pm 1.4$ & $54.5 \pm 5.9$ & $45.4 \pm 2.5$ & $40.9 \pm 0.8$ & $2.1 \pm 0.8$ \\
\hline
\end{tabular}

data are expressed as percentage of growth inhibition \pm standard deviation

TABLE IV

Cytotoxic effects on A549, H292, HCT116, MCF7, SK-MEL-5 and HS5 cells of Artemisia absinthium vapour pressure (VP) essential oil (T2-11) and fractions VLC1-VLC9

\begin{tabular}{|c|c|c|c|c|c|c|c|}
\hline \multirow{2}{*}{$\begin{array}{l}\text { VP } \\
\text { and fractions }\end{array}$} & \multirow{2}{*}{$\begin{array}{l}\text { Concentration } \\
(\mu \mathrm{g} / \mathrm{mL})\end{array}$} & \multicolumn{6}{|c|}{ Cell lines } \\
\hline & & A549 & H 292 & HCT116 & MCF7 & SKMEL-5 & HS5 \\
\hline \multirow[t]{2}{*}{ VP T2-11 } & 250 & $79.5 \pm 0.4$ & $76.7 \pm 1.1$ & $51.1 \pm 1.8$ & $91.3 \pm 0.9$ & $60.1 \pm 3.1$ & $80.5 \pm 3.4$ \\
\hline & 100 & $98.6 \pm 5.2$ & $82.5 \pm 1.0$ & $58.5 \pm 3.5$ & $95.7 \pm 1.8$ & $78.5 \pm 0.9$ & $86.7 \pm 0.9$ \\
\hline \multirow[t]{2}{*}{ VLC-1 } & 250 & $60.6 \pm 1.5$ & $73.0 \pm 0.9$ & $49.6 \pm 1.3$ & $95.7 \pm 1.8$ & $58.2 \pm 0.8$ & $80.8 \pm 1.5$ \\
\hline & 100 & $74.8 \pm 1.9$ & $77.2 \pm 3.2$ & $52.1 \pm 0.8$ & $91.3 \pm 0.9$ & $56.9 \pm 3.0$ & $79.1 \pm 2.4$ \\
\hline \multirow[t]{2}{*}{ VLC-2 } & 250 & $84.0 \pm 4.7$ & $89.2 \pm 7.8$ & $59.4 \pm 4.2$ & $84.0 \pm 9.8$ & $58.8 \pm 10.5$ & $91.7 \pm 6.8$ \\
\hline & 100 & $69.5 \pm 10.2$ & $90.4 \pm 2.0$ & $59.5 \pm 3.6$ & $89.6 \pm 2.1$ & $67.7 \pm 5.2$ & $83.3 \pm 7.4$ \\
\hline \multirow[t]{2}{*}{ VLC-3 } & 250 & $83.6 \pm 4.2$ & $97.2 \pm 7.1$ & $59.0 \pm 1.4$ & $91.9 \pm 3.5$ & $57.3 \pm 5.7$ & $90.2 \pm 5.2$ \\
\hline & 100 & $100 \pm 9.1$ & $98.1 \pm 5.4$ & $63.4 \pm 0.9$ & $93.3 \pm 0.5$ & $66.3 \pm 5.5$ & $84.1 \pm 4.3$ \\
\hline \multirow[t]{2}{*}{ VLC-4 } & 250 & $80.6 \pm 2.5$ & $73.5 \pm 3.1$ & $63.9 \pm 1.3$ & $88.7 \pm 0.2$ & $57.4 \pm 1.0$ & $78.5 \pm 2.5$ \\
\hline & 100 & $95.9 \pm 2.3$ & $79.9 \pm 0.8$ & $78.5 \pm 0.6$ & $100 \pm 0.7$ & $58.8 \pm 1.6$ & $86.1 \pm 1.8$ \\
\hline \multirow[t]{2}{*}{ VLC-5 } & 250 & $57.7 \pm 1.3$ & $78.1 \pm 0.6$ & $51.7 \pm 1.5$ & $80.1 \pm 3.7$ & $54.1 \pm 2.1$ & $75.9 \pm 1.7$ \\
\hline & 100 & $95.2 \pm 3.1$ & $79.7 \pm 1.3$ & $62.8 \pm 3.6$ & $97.3 \pm 2.3$ & $53.5 \pm 3.9$ & $68.2 \pm 1.8$ \\
\hline \multirow[t]{2}{*}{ VLC-6 } & 250 & $100 \pm 2.5$ & $87.8 \pm 3.9$ & $64.4 \pm 2.2$ & $96.9 \pm 2.3$ & $59.5 \pm 4.2$ & $81.2 \pm 2.9$ \\
\hline & 100 & $100 \pm 2.7$ & $96.8 \pm 1.8$ & $75.0 \pm 2.7$ & $100 \pm 1.1$ & $72.0 \pm 1.3$ & $90.7 \pm 3.7$ \\
\hline \multirow[t]{2}{*}{ VLC-7 } & 250 & $100 \pm 3.4$ & $94.4 \pm 1.1$ & $93.1 \pm 1.9$ & $93.7 \pm 1.6$ & $69.5 \pm 8.9$ & $89.1 \pm 1.8$ \\
\hline & 100 & $100 \pm 2.3$ & $100 \pm 1.7$ & $93.6 \pm 2.3$ & $97.9 \pm 1.9$ & $78.4 \pm 5.1$ & $95.7 \pm 2.1$ \\
\hline \multirow[t]{2}{*}{ VLC-8 } & 250 & $67.7 \pm 4.6$ & $82.8 \pm 13.6$ & $50.9 \pm 2.0$ & $69.1 \pm 2.3$ & $54.5 \pm 1.9$ & $76.3 \pm 3.9$ \\
\hline & 100 & $100 \pm 2.4$ & $87.2 \pm 5.2$ & $65.0 \pm 0.6$ & $100 \pm 1.7$ & $54.5 \pm 2.8$ & $86.6 \pm 2.8$ \\
\hline \multirow[t]{2}{*}{ VLC-9 } & 250 & $100 \pm 0.2$ & $92.5 \pm 6.0$ & $96.8 \pm 1.6$ & $97.8 \pm 1.7$ & $65.9 \pm 6.0$ & $95.6 \pm 1.7$ \\
\hline & 100 & $100 \pm 3.1$ & $97.4 \pm 5.0$ & $89.6 \pm 3.5$ & $96.1 \pm 1.7$ & $79.3 \pm 2.1$ & $95.4 \pm 2.1$ \\
\hline Paclitaxel & 85 & $41.9 \pm 2.9$ & $41.8 \pm 1.7$ & $40.2 \pm 2.8$ & $52.9 \pm 3.5$ & $34.9 \pm 2.4$ & $27.7 \pm 4.8$ \\
\hline Cisplatin & 300 & $34.6 \pm 1.5$ & $57.3 \pm 2.6$ & $25.7 \pm 1.7$ & $65.6 \pm 1.1$ & $42.6 \pm 0.3$ & $22.8 \pm 2.4$ \\
\hline
\end{tabular}

paclitaxel and cisplatin are included as drugs reference. Data are expressed as viability percentage \pm standard deviation relative to vehicle-treated control cells. 


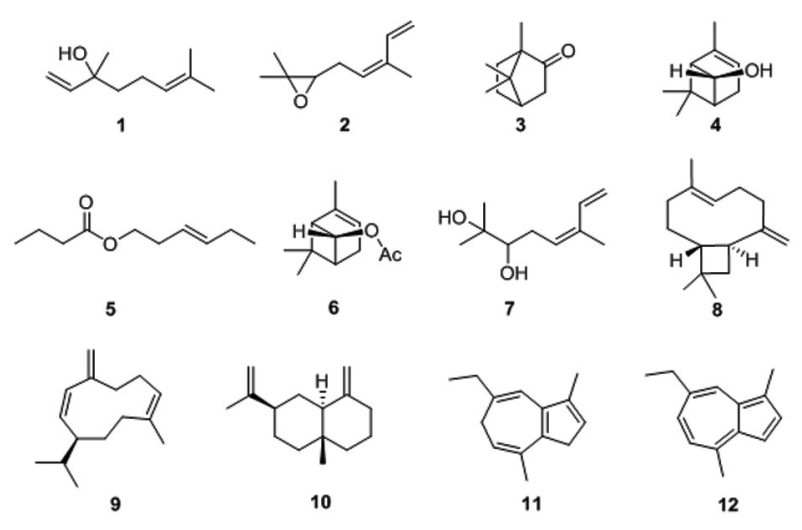

Chemical structures of linalool (1), cis-epoxycimene (2), camphor (3), (-)-cis-chrysanthenol (4), (E)-3-hexenyl butyrate (5), chrysanthenyl acetate (6), (-)-(5Z)-2,6-dimethylocta-5,7-diene-2,3-diol (7), transcaryophyllene (8), germacrene-D (9), $\beta$-selinene (10), 3,6-dihydrochamazulene (11) and chamazulene (12).

been reported to be a potent hydroxyl radical scavenger capable to effectively inhibit lipid peroxidation (Siveen \& Kuttan 2011, Ornano et al. 2013) and possess antiinflammatory activity in vivo, by inhibiting the leukotriene synthesis and lipid peroxidation (Safayhi et al. 1994, Rekka et al. 1996). However there are no reports on antiparasitic effects of chamazulene or dihydrochamazulene.

trans-caryophyllene has been reported as antinociceptive (Katsuyama et al. 2013), anxiolytic, antidepressant (Bahi et al. 2014) and antimicrobial (Goren et al. 2011), among other effects. EOs rich in trans-caryophyllene and caryophyllene oxide from different plant species have been tested on T. cruzi, T. vaginalis (Vermani \& Garg 2002, Cheikh-Ali et al. 2011, Polanco-Hernández et al. 2012, 2013, Costa et al. 2013, da Silva et al. 2013, Monzote et al. 2014) and other protozoan parasites such as Trypanosoma brucei, Plasmodium falciparum and $L$. infantum (Nibret \& Wink 2010, Gachet et al. 2011, Monzote et al. 2014), with different activity ranges alone or showing synergistic effects with the different EO components (Setzer et al. 2007, Polanco-Hernández et al. 2012, 2013). In our study, trans-caryophyllene was effective against T. cruzi and T. vaginalis, but the activity of fraction VLC1 is not fully explained by its content in trans-caryophyllene, suggesting synergistic effects.

In summary, the most interesting compounds are trans-caryophyllene (main compound in fraction VLC1), for its demonstrated antiparasitic and cytotoxic activity and 3,6-dihydrochamazulene, because of the activity of fraction VLC2; both compounds present in the A. absinthium var. candial ${ }^{\circledR}$ VP EO.

\section{REFERENCES}

Ariño A, Arberas I, Renobales G, Arriaga S, Dominguez JB 1999. Essential oil of Artemisia absinthium L. from the Spanish Pyrenees. J Essent Oil Res 11: 182-184.

Bachrouch O, Ferjani N, Haouel S, Jemâa JMB 2015. Major compounds and insecticidal activities of two Tunisian Artemisia essential oils toward two major coleopteran pests. Ind Crops Prod 65: 127-133.
Bahi A, Al Mansouri S, Al Memari E, Al Ameri M, Nurulain SM, Ojha S 2014. $\beta$-caryophyllene, a CB2 receptor agonist produces multiple behavioral changes relevant to anxiety and depression in mice. Physiol Behav 135: 119-124.

Bailén M, Julio LF, Díaz CE, Sanz J, Martínez-Díaz RA, Cabrera R, Burillo J, González-Coloma A 2013. Chemical composition and biological effects of essential oils from Artemisia absinthium L. cultivated under different environmental conditions. Ind Crops Prod 49: 102-107.

Bora KS, Sharma A 2010. Phytochemical and pharmacological potential of Artemisia absinthium Linn. and Artemisia asiatica Nakai: a review. J Pharm Res 3: 325-328.

Burillo J 2009. Cultivo experimental de ajenjo Artemisia absinthium L. como potencial insecticida de origen natural. In J Burillo, A González-Coloma, Insecticidas y repelentes de origen natural, Centro de Investigación y Tecnología Agroalimentaria, Zaragoza, p. 19-30.

Carnat AP, Madesclaire M, Chavignon O, Lamaison JI 1992. cischrysanthenol, a main component in essential oil of Artemisia absinthium L. growing in Auvergne (Massif Central) France. $J$ Essent Oil Res 4: 487-490.

Cheikh-Ali Z, Adiko M, Bouttier S, Bories C, Okpekon T, Poupon E, Champy P 2011. Composition and antimicrobial and remarkable antiprotozoal activities of the essential oil of rhizomes of Aframomum sceptrum K. Schum. (Zingiberaceae). Chem Biodivers 8: 658-667.

Chialva F, Liddle PAP, Doglia G 1983. Chemotaxonomy of wormwood (Artemisia absinthum L.) I. Composition of the essential oil of several chemotypes. Z Lebensm Unters Forsch 176: 363-366.

Costa EV, Dutra LM, Salvador MJ, Ribeiro LH, Gadelha FR, de Carvalho JE 2013. Chemical composition of the essential oils of Annona pickelii and Annona salzmannii (Annonaceae) and their antitumour and trypanocidal activities. Nat Prod Res 27: 997-1001.

Cudmore SL, Delgaty KL, Hayward-McClelland SF, Petrin DP, Garber GE 2004. Treatment of infections caused by metronidazoleresistant Trichomonas vaginalis. Clin Microbiol Rev 17: 783-793.

da Silva TB, Menezes LR, Sampaio MF, Meira CS, Guimarães ET, Soares MB, Prata AP, Nogueira PC, Costa EV 2013. Chemical composition and anti-Trypanosoma cruzi activity of essential oils obtained from leaves of Xylopia frutescens and X. laevigata (Annonaceae). Nat Prod Commun 8: 403-406.

Dunne RL, Dunn LA, Upcroft P, O’Donoghue PJ, Upcroft JA 2003. Drug resistance in the sexually transmitted protozoan Trichomonas vaginalis. Cell Res 13: 239-249.

el Hadri A, del Río MAG, Sanz J, González-Coloma A, Idaomar M, Ozonas BR, González JB, Reus MIS 2010. Cytotoxic activity of $\alpha$-humulene and transcaryophyllene from Salvia officinalis in animal and human tumor cells. An R Acad Nac Farm 76: 343-356.

Erel S, Reznicek G, Senol SG, Yavasogulu NÜK, Konyalioglu S, Zeybek AU 2012. Antimicrobial and antioxidant properties of Artemisia L. species from western Anatolia. Turk J Biol 36: 75-84.

Escribano AI, Marcel AM, Tugores YM, Ruiz JJN, Redó VJA, García-Trevijano JAE, Barrio AG 2012. Validation of a modified fluorimetric assay for the screening of trichomonacidal drugs. Mem Inst Oswaldo Cruz 107: 637-643.

Gachet MS, Kunert O, Kaiser M, Brun R, Zeh1 M, Keller W, Muñoz RA, Bauer R, Schuehly W 2011. Antiparasitic compounds from Cupania cinerea with activities against Plasmodium falciparum and Trypanosoma brucei rhodesiense. J Nat Prod 74: 559-566.

Geszprych A, Przybyl J, Kuczerenko A, Weglarz Z 2010. Diversity of wormwood (Artemisia absinthium L.) growing wild in Poland in 
respect of the content and composition of essential oil and phenolic compounds. ISHS Acta Horticulturae 925: 123-129.

González-Coloma A, Bailen M, Díaz CE, Fraga BM, Martínez-Díaz R, Zuñiga GE, Contreras RA, Cabrera R, Burillo J 2012a. Major components of Spanish cultivated Artemisia absinthium populations: antifeedant, antiparasitic andantioxidant effects. Ind Crops Prod 37: 401-407.

González-Coloma A, Reina M, Sáenz C, Lacret R, Ruiz-Mesia L, Arán VJ, Sanz J, Martínez-Díaz RA 2012b. Antileishmanial, antitrypanosomal and cytotoxic screening of ethnopharmacologically selected Peruvian plants. Parasitol Res 110: 1381-1392.

Goren AC, Piozzi F, Akcicek E, Kılıc T, ÇarıkÇi S, Mozioglu E, Setzer WN 2011. Essential oil composition of twenty-two Stachys species (mountain tea) and their biological activities. Phytochem Lett 4: 448-453.

Jaenson T, Pålsson K, Borg-Karlson AK 2005. Evaluation of extracts and oils of tick-repellent plants from Sweden. Med Vet Entomol 19: 345-352.

Jamalian A, Shams-Ghahfarokhi M, Jaimand K, Pashootan N, Amani A, Razzaghi-Abyaneh M 2012. Chemical composition and antifungal activity of Matricaria recutita flower essential oil against medically important dermatophytes and soil-borne pathogens. $J$ Mycol Med 22: 308-315.

Judzentiene A, Budiene J, Gircyte R, Masotti V, Laffont-Schwob I 2012. Toxic activity and chemical composition of Lithuanian wormwood (Artemisia absinthium L.) essential oils. Rec Nat Prod 6: 180-183.

Juteau F, Jerkovic I, Masotti V, Milos M, Mastelic J, Bessière JM, Viano J 2003. Composition and antimicrobial activity of the essential oil of Artemisia absinthium from Croatia and France. Planta Med 69: 158-161.

Katsuyama S, Mizoguchi H, Kuwahata H, Komatsu T, Nagaoka K, Nakamura H, Bagetta G, Sakurada T, Sakurada S 2013. Involvement of peripheral cannabinoid and opioid receptors in $\beta$-caryophylleneinduced antinociception. Eur J Pain 17: 664-675.

Kordali S, Kotan R, Mavi A, Cakir A, Ala A, Yildirim A 2005. Determination of the chemical composition and antioxidant activity of the essential oil of Artemisia dracunculus and of the antifungal and antibacterial activities of Turkish Artemisia absinthium, A. dracunculus, Artemisia santonicum and Artemisia spicigera essential oils. J Agric Food Chem 53: 9452-9458.

Lachenmeier DW 2010. Wormwood (Artemisia absinthium L.) - a curious plant with both neurotoxic and neuroprotective properties? J Ethnopharmacol 131: 224-227.

Martín L, Julio LF, Burillo J, Sanz J, Mainar AM, González-Coloma A 2011. Comparative chemistry and insect antifeedant action of traditional (Clevenger and Soxhlet) and supercritical extracts $\left(\mathrm{CO}_{2}\right)$ of two cultivated wormwood (Artemisia absinthium L.) populations. Ind Crops Prod 34: 1615-1621.

Monzote L, García M, Pastor J, Gil L, Scull R, Maes L, Cos P, Gille L 2014. Essential oil from Chenopodium ambrosioides and main components: activity against Leishmania, their mitochondria and other microorganisms. Exp Parasitol 136: 20-26.

Nasrabadi HG, Abbaszadeh S, Hashtjin NT, Yamrali I 2012. Study of chemical composition of essential oil of afsantine (Artemisia absinthium) and inhibitory effects of the essential oil and its aqueous and alcoholic extracts on some food borne bacterial pathogens. J Med Plants 11: 120-127.
Nibret E, Wink M 2010. Trypanocidal and antileukaemic effects of the essential oils of Hagenia abyssinica, Leonotis ocymifolia, Moringa stenopetala and their main individual constituents. Phytomedicine 17: 911-920.

Ornano L, Venditti A, Ballero M, Sanna C, Quassinti L, Bramucci M, Lupidi G, Papa F, Vittori S, Maggi F, Bianco A 2013. Chemopreventive and antioxidant activity of the chamazulene-rich essential oil obtained from Artemisia arborescens L. growing on the isle of La Maddalena, Sardinia, Italy. Chem Biodivers 10: 1464-1474.

Pino JA, Rosado A, Fuentes V 1997. Chemical composition of the essential oil of Artemisia absinthium L. from Cuba. J Essent Oil Res 9: 87-89.

Polanco-Hernández G, Escalante-Erosa F, García-Sosa K, ChanBacab MJ, Sagua-Franco H, González J, Osorio-Rodríguez L, Peña-Rodríguez LM 2012. Metabolites from the leaf extract of Serjania yucatanensis with trypanocidal activity against Trypanosoma cruzi. Parasitol Res 111: 451-455.

Polanco-Hernández G, Escalante-Erosa F, García-Sosa K, Rosado ME, Guzmán-Marín E, Acosta-Viana KY, Giménez-Turba A, Salamanca E, Peña-Rodríguez LM 2013. Synergistic effect of lupenone and caryophyllene oxide against Trypanosoma cruzi. $J$ Evid Based Complementary Altern Med 2013: 6 pp.

Rassi Jr A, Rassi A, Marin-Neto A 2010. Chagas disease. Lancet 375: 1388-1402.

Rekka EA, Kourounakis AP, Kourounakis PN 1996. Investigation of the effect of chamazulene on lipid peroxidation and free radical processes. Res Commun Mol Pathol Pharmacol 92: 361-364.

Safayhi H, Sabieraj J, Sailer ER, Ammon HP 1994. Chamazulene: an antioxidant-type inhibitor of leukotriene B4 formation. Planta Med 60: 410-413.

Setzer W, Stokes S, Bansal A, Haber W, Caffrey C, Hansell E, McKerrow J 2007. Chemical composition and cruzain inhibitory activity of Croton draco bark essential oil from Monteverde, Costa Rica. Nat Prod Commun 2: 685-689.

Sharopov FS, Sulaimonova VA, Setzer WN 2012. Composition of the essential oil of Artemisia absinthium from Tajikistan. Rec Nat Prod 6: 127-134.

Siveen KS, Kuttan G 2011. Augmentation of humoral and cell mediated immune responses by Thujone. Int Immunopharmacol 11: 1967-1975.

Tariku Y, Hymete A, Hailu A, Rohloff J 2011. In vitro evaluation of antileishmanial activity and toxicity of essential oils of Artemisia absinthium and Echinops kebericho. Chem Biodivers 8: 614-623.

Tehrani MS, Azar PA, Hosain SW, Khalilzadeh MA, Zanousi MBP 2012. Composition of essential oil of Artemisia absinthium by three different extraction methods: hydrodistillation, solvent-free microwave extraction and headspace solid-phase microextraction. Asian J Chem 24: 5371-5376.

Umpiérrez ML, Lagreca ME, Cabrera R, Grille G, Rossini C 2012. Essential oils from Asteraceae as potential biocontrol tools for tomato pests and diseases. Phytochem Rev 11: 339-350.

Vermani K, Garg S 2002. Herbal medicines for sexually transmitted diseases and AIDS. J Ethnopharmacol 80: 49-66.

WHO - World Health Organization 2012. Global incidence and prevalence of selected curable sexually transmitted infections - 2008. Available from: apps.who.int/iris/bitstream/10665/75181/1/97892 41503839 eng.pdf?ua=1. 